\title{
FAKTOR-FAKTOR YANG MEMPENGARUHI KEPATUHAN PASIEN GANGGUAN JIWA MELAKUKAN PENGOBATAN RUTIN KE PUSKESMAS SIDODADI KECAMATAN KOTA KISARAN BARAT KABUPATEN ASAHAN TAHUN 2018
}

\author{
Elisabeth Dame Manalu, Nina Dwi Yanti Siagian \\ Institut Kesehatan Deli Husada Delitua \\ e-mail: manalupanjaitan@gmail.com
}

\begin{abstract}
Mental health is a state where one is free from mental disorders and has a positive attitude to describe maturity and personality. Based on preliminary studies at Sidodadi Public Health Center, patients suffering from anxiety as many as 26 people and patients suffering from depression as many as 38 people. The purpose of this study is to determine the factors that influence the patient's compliance with mental disorders doing routine treatment to Sidodadi Health Center District West Kisaran City Asahan Region 2018, with the type of quantitative writing that is analytic. The population in this writing is the entire head of the family of patients who have mental disorders anxiety and depression that is as many as 64 people. The sampling technique used is total sampling. Data were collected by interviews using the questionnaire. Data analysis was done univariate and bivariate with the Pearson correlation test. The findings of the research showed that there was significant influence between family attitudes, family support, the distance of Health Center, support of health workers. The most dominant variable that influenced the patient's compliance with mental disorder to do routine treatment is the support of health manpower 5.8 times. Head of Health Center to encourage health workers to continue to visit the family home of mental disorders so that they can help the healing process or care for people with mental disorders.
\end{abstract}

Keywords: compliance, routine treatment, mental disorders

\section{PENDAHULUAN}

Konsep gangguan jiwa dari PPDGJ III yang merujuk ke DSM-III adalah sindrom atau pola perilaku, atau psikologi seseorang, yang secaraklinik cukup bermakna, dan yang secara khas berkaitan dengan suatugejala penderitaan (distress) atau hendaya (impairment/disability) di dalam satu atau lebih fungsi yang penting dari manusia (Maslim, 2002). Menurut data WHO pada tahun 2013 angka penderita gangguan jiwa mengkhawatirkan secara global, sekitar 450 juta orang yang menderita gangguan mental. Orang yang mengalami gangguan jiwa sepertiganya tinggal di negara berkembang, sebanyak 8 dari 10 penderita gangguan mental itu tidak mendapatkan perawatan (Kemenkes RI, 2014).

Meskipun penderita gangguan jiwa belum bisa disembuhkan $100 \%$, tetapi para penderita gangguan jiwa memiliki hak untuk sembuh dan diperlakukan secara manusiawi. UU RI No. 18
Tahun 2014 Bab I Pasal 3 Tentang Kesehatan Jiwa telah dijelaskan bahwa upaya kesehatan jiwa bertujuan menjamin setiap orang dapat mencapai kualitas hidup yang baik, menikmati kehidupan kejiwaan yang sehat, bebas dari ketakutan, tekanan dan gangguan lain yang dapat mengganggu kesehatatan jiwa (Kemenkes, 2014). Menurut Departemen Kesehatan Republik Indonesia Kemenkes RI (2012), gangguan jiwa saat ini telah menjadi masalah kesehatan global bagi setiap negara tidak hanya di Indonesia saja. Gangguan jiwa yang dimaksud tidak hanya gangguan jiwa psikotik/ skizofrenia saja tetapi kecemasan, depresi dan penggunaan Narkoba Psikotropika dan Zat adiktif lainnya (NAPZA) juga menjadi masalah gangguan jiwa. Indonesia mengalami peningkatan jumlah penderita gangguan jiwa cukup banyak diperkirakan prevalensi gangguan jiwa berat dengan psikosis/ skizofrenia di Indonesia pada tahun 2013 adalah 1.728 orang. Adapun proposi rumah tangga yang 


\begin{tabular}{l|r|r}
\hline Jurnal Penelitian Kesmasy & Vol. 2 No. 1 & Edition: May - October 2019 \\
\hline \multirow{2}{*}{ Received: 24 October 2019 } & http://ejournal.delihusada.ac.id/index.php/JPKSY & \\
\cline { 2 - 2 } & Revised: 28 October 2019 & Accepted: 31 October 2019
\end{tabular}

pernah memasung penderita gangguan jiwa berat sebesar 1.655 rumah tangga dari $14,3 \%$ terbanyak tinggal di pedasaan, sedangkan yang tinggal diperkotaan sebanyak $10,7 \%$. Selain itu prevalensi gangguan mental emosional pada penduduk umur lebih dari 15 tahun di Indonesia secara nasional adalah $6.0 \%$ (37.728 orang dari subjek yang dianalisis). Provinsi dengan prevalensi gangguan mental emosional tertinggi adalah Sulawesi Tengah (11,6\%), Sedangkan yang terendah di Lampung (1,2\%) (Riset Kesehatan Dasar, 2013). Menurut data yang diperoleh dari Rekam Medik Rumah Sakit Jiwa Daerah Provinsi Sumatera Utara tahun 2014, pasien gangguan jiwa yang dirawat jalan berjumlah 15.720 orang.

Penelitian Ahyar (2010) menyebutkan bahwa $75 \%$ pasien akan menghentikan pengobatannya dalam waktu 18 bulan pertama, dan pasien yang menghentikan pengobatan antipsikotik tersebut memiliki peluang 5 kali lebih besar untuk kambuh (Irma, 2011). Salah satu faktor utama keberhasilan penatalaksanaan terapi penyakit gangguan jiwa adalah kontinuitas pengobatan. Ketidakpatuhan dalam pengobatan antipsikotik pada pasien skizofrenia lazim terjadi, tingkat kepatuhan minum obat pada populasi pasien skizofrenia mulai dari $20 \%$ hingga $89 \%$.Ketidakpatuhan secara umum pada populasi pasien skizofrenia mencapai $50 \%$ dan pada dua tahun pertama saat episode psikotik dan meningkat menjadi 55\%.Ketidakpatuhan pada pasien gangguan jiwa berhubungan erat dengan meningkatnya angka masuk rumah sakit, biaya kesehatan, kekambuhan, keinginan bunuh diri, dan kematian (Siswono, 2014).

Pentingnya keluarga berperan dalam merawat pasien gangguan jiwa agar pasien teratur dalam melaksanakan terapi dan untuk kesembuhan pasien tersebut. Keluarga yang merupakan orang terdekat dengan pasien mempunyai peranan penting dalam kesembuhan pasien salah satunya yaitu dukungan informasi dimana jenis dukungan ini meliputi jaringan komunikasi dan tanggung jawab bersama yaitu termasuk di dalamnya memberikan solusi dari masalah, memberikan nasehat, pengarahan, saran atau umpan balik tentang apa yang dilakukan seseorang, selain itu keluarga sebagai menyediakan informasi untuk melakukan konsultasi yang teratur ke rumah sakit dan terapi yang baik bagi dirinya dan tindakan spesifik bagi pasien untuk melawan stressor (Copel, 2011).

Penelitian yang telah dilakukan Irma (2011) menyatakan bahwa ada hubungan yang signifikan antara dukungan keluarga dengan kepatuhan pasien minum obat. Penelitian Mustafa (2016) menggunakan populasi yaitu keluarga yang membawa pasien kontrol ulang ke poliklinik rumah sakit jiwa menyatakan ada hubungan dukungan keluarga dengan kepatuhan pasien berobat. Hasil penelitian ini diperkuat dengan penelitian yang dilakukan Garcia (2014) yang menyebutkan bahwa keluarga memberikan dukungan yang adekuat dan terus-menerus selama pasien di rawat baik dukungan pengharapan, nyata, informasi dan dukungan emosional.

Studi pendahuluan di Dinas Kesehatan Asahan bahwa berdasarkan data bulan Desember 2017 sampai dengan April 2018 pasien yang mengalami ansietas sebanyak 119 orang dan pasien yang mengalami depresi sebanyak 71 pasien. Pengambilan data secara acak sejumlah 5 orang didapatkan perbandingan data 2 orang pasien yang rutin berkunjung untuk memeriksakan penyakit gangguan jiwa sedangkan 3 orang tidak rutin berkunjung, 1 orang diantaranya satu kali tidak kontrol, 1 orang lainnya dua kali tidak kontrol, dan 1 orang lainnya tidak kontrol 3 kali.

Beberapa kerangka teori yang dapat menjelaskan perilaku kepatuhan pasien dalam melaksanakan pengobatan, salah satunya adalah Theory Planned Behavior (TPB) yaitu teori yang mengeksplorasi hubungan antara perilaku, kepercayaan, sikap, dan intention (Akbar, 2010).

Theory of Planned Behavior merupakan prediksi perilaku yang merupakan pendekatan psikologisosial untuk pemahaman dan memprediksi beberapa faktor penentu perilaku kesehatan. Pada teori ini, perilaku dipengaruhi oleh niat untuk melakukan perilaku. Dimana niat itu dipengaruhi oleh tiga faktor penentu apakah niat itu dapat menghasilkan perilaku. Tiga faktor itu yaitu faktor personal adalah sikap umum 


\begin{tabular}{l|r|r}
\hline Jurnal Penelitian Kesmasy & Vol. 2 No. 1 & Edition: May - October 2019 \\
\hline \multirow{2}{*}{ Received: 24 October 2019 } & http://ejournal.delihusada.ac.id/index.php/JPKSY & \multirow{2}{*}{ Accepted: 31 October 2019 } \\
\cline { 2 - 3 } & Revised: 28 October 2019 &
\end{tabular}

seseorang terhadap sesuatu, yaitu sifat kepribadian (personality traits), nilai hidup (values), emosi, dan kecerdasan yang dimilikinya. Faktor sosial antara lain usia, jenis kelamin (gender), etnis, pendidikan, penghasilan, dan agama. Faktor informasi adalah pengalaman, pengetahuan, dan ekspose pada media (Hawari, 2011).

Berdasarkan studi pendahuluan di Puskesmas Sidodadi, pasien yang menderita ansietas sebanyak 26 orang dan pasien yang menderita depresi sebanyak 38 orang. Berdasarkan hasil wawancara dengan perawat yang memegang program jiwa di puskesmas tentang penatalaksanaan pasien gangguan jiwa bahwa pasien depresi dan ansietas tidak rutin dalam melakukan pengobatan. Rata-rata kunjungan pasien ansietas per minggu sebanyak 3-7 orang bahkan sebagian keluarga yang menjemput obat pasien ke Puskesmas tanpa membawa pasien. Untuk penanganan pasien di Puskesmas Sidodadi membentuk kader sehat jiwa tapi belum berjalan optimal dan home visit oleh petugas puskesmas juga belum optimal karena keterbatasan tenaga.

Studi pendahuluan juga dilakukan pada lima keluarga pasien gangguan jiwa. Tiga dari lima keluarga yang dikaji tidak teratur minum obat dengan berbagai alasan. Alasan yang ditemukan terkait pengobatan antara lain pasien tidak minum obat karena keluarga merasa tidak perlu diobati, pasien tidak minum obat karena bosan, pasien minum obat semaunya karena tidak diawasi oleh keluarga. Hal ini menunjukan bahwa pasien memerlukan dukungan keluarga untuk meningkatkan kepatuhan pasien minum obat.

Di waktu yang sama peneliti juga menanyakan dukungan yang diberikan keluarga, tiga dari lima keluarga melakukan perawatan diri pasien dengan ikhlas, mengantar pasien berobat, mengawasi pasien minum obat, dan mengajak pasien beraktivitas dan dua orang lagi mengatakan bahwa memberikan perhatian, merasa menyayanginya dan tetap dalam kondisi apapun menanggap bahwa pasien adalah orang yang harus ditolong dan dirawat.

Dari uraian tersebut, maka peneliti bertujuan untuk mengetahui: 1) faktor-faktor yang mempengaruhi kepatuhan pasien gangguan jiwa melakukan pengobatan rutin, 2) pengaruh sikap keluarga, dukungan keluarga, jarak puskesmas, dukungan tenaga kesehatan terhadap kepatuhan pasien gangguan jiwa melakukan pengobatan rutin Ke Puskesmas Sidodadi Kecamatan Kota Kisaran Barat Kabupaten Asahan Tahun 2018.

\section{METODE}

Jenis penelitian ini adalah bersifat analitik dengan desain penelitian cross sectional. Populasi pada penelitian ini adalah seluruh kepala keluarga pasien yang mengalami gangguan jiwa ansietas dan depresi sebanyak 64 orang dengan teknik pengambilan sampel yang digunakan adalah total sampling. Data yang diperoleh kemudian dianalisis menggunakan uji analisis univariat dan multivariat dengan rumus uji statistik chi square.

\section{HASIL DAN PEMBAHASAN}

\section{Hasil Penelitian Univariat}

Hasil penelitian terhadap 64 orang responden berdasarkan karakteristik responden gangguan jiwa melakukan pengobatan rutin dapat dilihat pada tabel 1. di bawah ini, yakni:

Tabel 1. Karakteristik Responden

\begin{tabular}{lcc}
\hline Kategori & $\mathrm{n}$ & $\%$ \\
\hline Sikap Keluarga & & \\
Baik & 27 & 42,2 \\
$\begin{array}{l}\text { Kurang baik } \\
\text { Dukungan Keluarga }\end{array}$ & 37 & 57,8 \\
$\begin{array}{l}\text { Baik } \\
\text { Kurang baik }\end{array}$ & 33 & 51,6 \\
Jarak puskesmas & 31 & 48,4 \\
$\begin{array}{l}\text { Dekat } \\
\text { Jauh }\end{array}$ & 25 & 39.1 \\
$\begin{array}{l}\text { Dukungan tenaga Medis } \\
\text { Mendukung }\end{array}$ & 39 & 60,9 \\
$\begin{array}{l}\text { Tidak mendukung } \\
\text { Kepatuhan Pasien Melakukan }\end{array}$ & 25 & 39.1 \\
$\begin{array}{l}\text { Pengobatan Rutin } \\
\text { Patuh }\end{array}$ & 39 & 60,9 \\
Tidak patuh & & \\
\hline
\end{tabular}

Berdasarkan tabel di atas dapat dilihat variabel sikap keluarga dalam kategori kurang baik sejumlah 37 orang atau sebesar $57,8 \%$. Berdasarkan dukungan keluarga dalam kategori baik sejumlah 33 orang atau sebesar $51,6 \%$. 


\begin{tabular}{l|r|r}
\hline Jurnal Penelitian Kesmasy & Vol. 2 No. 1 & Edition: May - October 2019 \\
\hline \multirow{2}{*}{ Received: 24 October 2019 } & http://ejournal.delihusada.ac.id/index.php/JPKSY & \multirow{2}{*}{ Accepted: 31 October 2019 } \\
\cline { 2 - 3 } & Revised: 28 October 2019 &
\end{tabular}

Berdasarkan jarak puskesmas dalam kategori jauh sejumlah 39 orang atau sebesar 60,9\%. Berdasarkan dukungan tenaga kesehatan dalam kategori tidak mendukung sejumlah 39 orang atau sebesar $60,9 \%$. Berdasarkan kepatuhan pasien gangguan jiwa melakukan pengobatan rutin dalam kategori tidak patuh sejumlah 36 orang atau sebesar $56,3 \%$.

\section{Pengaruh Sikap Keluarga Terhadap Kepatuhan Pasien Melakukan Pengobatan Rutin}

Hasil analisis bivariat dari variabel pengaruh sikap keluarga terhadap kepatuhan pasien gangguan jiwa melakukan pengobatan rutin ke Puskesmas Sidodadi Kecamatan Kota Kisaran Barat Kabupaten Asahan Tahun 2018, dapat lebih rinci pada tabel 2 di bawah ini:

Tabel 2 Pengaruh Sikap Keluarga Terhadap Kepatuhan Pasien Melakukan Pengobatan Rutin

\begin{tabular}{lccccc}
\hline \multirow{2}{*}{$\begin{array}{c}\text { Sikap } \\
\text { Keluarga }\end{array}$} & \multicolumn{2}{c}{$\begin{array}{c}\text { Kepatuhan } \\
\text { Pasien }\end{array}$} & Total & $\begin{array}{c}\text { P- } \\
\text { Value }\end{array}$ & $\begin{array}{c}\text { RP 95\% } \\
\text { CI }\end{array}$ \\
\cline { 2 - 3 } & Ya & Tidak & & & 8.769 \\
Baik & 25 & 2 & 27 & 0.032 & $(3.45-22.31)$ \\
\hline
\end{tabular}

Berdasarkan tabel di atas dapat dilihat bahwa keluarga yang memiliki sikap kurang baik tetapi patuh melakukan pengobatan rutin sebanyak 34 orang atau sekitar $91.89 \%$. Hasil uji statistik chi square diperoleh nilai $\mathrm{p}=0,032$ maka dapat disimpulkan bahwa ada pengaruh sikap keluarga terhadap kepatuhan pasien gangguan jiwa melakukan pengobatan rutin Ke Puskesmas Sidodadi Kecamatan Kota Kisaran Barat Kabupaten Asahan Tahun 2018. Nilai RP 8,769 pada $95 \%$ CI $(3.45-22,31)$, yang berarti pasien gangguan jiwa yang memiliki sikap keluarga baik 8,7 kali cendrung untuk patuh melakukan pengobatan rutin, dibanding dengan pasien gangguan jiwa yang memiliki sikap keluarga kurang baik.

Pada penelitian ini sikap keluarga berpengaruh terhadap kepatuhan pengobatan rutin pasien gangguan jiwa karena dapat membantu keluarga dalam perawatan pasien gangguan jiwa, beberapa keluarga pasien gangguan jiwa yang mengatakan bahwa pasien tidak patuh pengobatan rutin karena berbagai alasan diantaranya karena keluarga yang sangat sibuk dengan pekerjaannya dan tidak bisa menunggu pasien selama 24 jam terus dan tidak tahu pentingnya minum obat secara teratur bagi pasien gangguan jiwa. Hasil penelitian (Arisyanudin, 2015) yang menunjukkan bahwa keluarga berpengetahuan kurang sehingga dapat mempengaruhi kepatuahan minum obat pasien gangguan jiwa.

\section{Pengaruh Dukungan Keluarga Terhadap Kepatuhan Pasien Melakukan Pengobatan Rutin}

Hasil analisis bivariat dari variabel pengaruh dukungan keluarga terhadap kepatuhan pasien gangguan jiwa melakukan pengobatan rutin Ke Puskesmas Sidodadi Kecamatan Kota Kisaran Barat Kabupaten Asahan Tahun 2018, dapat lebih rinci pada tabel 3 di bawah ini:

Tabel 3 Pengaruh Dukungan Keluarga Terhadap Kepatuhan Pasien Melakukan Pengobatan Rutin

\begin{tabular}{|c|c|c|c|c|c|}
\hline \multirow{2}{*}{$\begin{array}{c}\text { Dukungan } \\
\text { Keluarga }\end{array}$} & \multicolumn{2}{|c|}{$\begin{array}{l}\text { Kepatuhan } \\
\text { Pasien }\end{array}$} & \multirow[t]{2}{*}{ Total } & \multirow{2}{*}{$\begin{array}{c}\text { P- } \\
\text { Value }\end{array}$} & \multirow{2}{*}{$\begin{array}{c}\text { RP 95\% } \\
\text { CI }\end{array}$} \\
\hline & $\mathbf{Y a}$ & Tidak & & & \\
\hline Baik & 15 & 18 & 33 & & 7.828 \\
\hline Kurang & 23 & 8 & 31 & 0.002 & $(2,62-23,35)$ \\
\hline
\end{tabular}

Berdasarkan tabel di atas dapat dilihat bahwa pasien gangguan jiwa yang mendapat dukungan keluarga kurang baik tetapi patuh melakukan pengobatan rutin sebanyak 23 orang atau sebanyak $74.2 \%$. Hasil uji statistik chi square diperoleh nilai $p=0,002$ maka dapat disimpulkan bahwa ada pengaruh dukungan keluarga terhadap kepatuhan pasien gangguan jiwa melakukan pengobatan rutin ke Puskesmas Sidodadi Kecamatan Kota Kisaran Barat Kabupaten Asahan Tahun 2018. Nilai RP 7,828 pada $95 \%$ CI $(2,62-$ $23,35)$, yang berarti pasien gangguan jiwa yang mendapat dukungan keluarga baik 7,8 kali cendrung untuk patuh melakukan pengobatan rutin, dibanding dengan pasien gangguan jiwa yang mendapat dukungan keluarga kurang baik.

Teori dukungan keluarga menurut Friedman (2010) dukungan keluarga adalah sikap, tindakan dan penerimaan keluarga terhadap penderita yang sakit. Dukungan keluarga sangat diperlukan oleh seorang penderita, karena seseorangyang 


\begin{tabular}{l|r|r}
\hline \multirow{2}{*}{ Jurnal Penelitian Kesmasy } & Vol. 2 No. 1 & Edition: May - October 2019 \\
\hline \multirow{2}{*}{ Received: 24 October 2019 } & $\frac{\text { http://ejournal.delihusada.ac.id/index.php/JPKSY }}{\text { Revised: 28 October 2019 }}$ & \multirow{2}{*}{ Accepted: 31 October 2019 }
\end{tabular}

sedang sakit tentunya membutuhkan perhatian dari keluarga.

Keluarga dapat berperan sebagai motivator terhadap anggota keluarganya yang sakit (penderita) sehingga mendorong penderita untuk terus berpikir positif terhadap sakitnya danpatuh terhadap pengobatan yang dianjurkan oleh tenaga kesehatan. Hasil penelitian ini sejalan dengan penelitian Violita (2015) yang menunjukan terdapat hubungan antara dukungan keluarga dengan kepatuhan minum obat gangguan jiwa. Hal ini dikarenakan responden yang dinyatakan patuh lebih banyak adalah merekayang memiliki dukungan keluarga yang baik. Sama halnya dalam penelitian Violita (2015), pada penelitian ini responden yang patuh (72\%) pada responden yang memiliki dukungan keluarga tinggi.

\section{Pengaruh Jarak Puskesmas Terhadap Kepatuhan Pasien Melakukan Pengobatan Rutin}

Hasil analisis bivariat dari variabel pengaruh jarak puskesmas terhadap kepatuhan pasien gangguan jiwa melakukan pengobatan rutin ke Puskesmas Sidodadi Kecamatan Kota Kisaran Barat Kabupaten Asahan Tahun 2018, dapat lebih rinci pada tabel 4 di bawah ini:

Tabel 4 Pengaruh Jarak Puskesmas Terhadap Kepatuhan Pasien Melakukan Pengobatan Rutin

\begin{tabular}{lccccc}
\hline \multirow{2}{*}{ Jarak } & \multicolumn{2}{c}{$\begin{array}{c}\text { Kepatuhan } \\
\text { Pasien }\end{array}$} & Total & $\begin{array}{c}\text { P- } \\
\text { Value }\end{array}$ & $\begin{array}{c}\text { RP 95\% } \\
\text { CI }\end{array}$ \\
\cline { 2 - 4 } & Ya & Tidak & & & \\
\hline Dekat & 17 & 8 & 25 & 0.004 & $\begin{array}{c}2,411 \\
\text { Jauh }\end{array}$ \\
\hline
\end{tabular}

Berdasarkan tabel di atas dapat dilihat bahwa pasien gangguan jiwa yang memiliki jarak puskesmas jauh dengan patuh melakukan pengobatan rutin sebanyak 11 orang atau sekitar 28.21\%. Hasil uji statistik chi square diperoleh nilai $p=0,004$ maka dapat disimpulkan bahwa ada pengaruh jarak puskesmas terhadap kepatuhan pasien gangguan jiwa melakukan pengobatan rutin Ke Puskesmas Sidodadi Kecamatan Kota Kisaran Barat Kabupaten Asahan Tahun 2018. Nilai RP 2,411 pada 95\% CI $(1,37-4,26)$, yang berarti pasien gangguan jiwa yang memiliki jarak puskesmas yang dekat 2,4 kali cendrung untuk patuh melakukan pengobatan rutin, dibanding dengan pasien gangguan jiwa yang memiliki jarak puskesmas yang jauh.

Keterjangkauan akses ke pelayanan kesehatan adalah mudah atau sulitnyaseseorang untuk mencapai tempat pelayanan kesehatan. Niven (2012) menyatakan bahwa salah satu faktor yang mempengaruhi kepatuhan berobat adalah factor yang mendukung (enabling factor), yang terdiri atas tersedianya fasilitas kesehatan, kemudahan untuk menjangkau sarana kesehatan serta keadaan social ekonomi dan budaya.

Rendahnya penggunaan fasilitas kesehatan seperti Puskesmas, rumah sakit dan sebagainya, seringkali kesalahan atau penyebabnya dilemparkan pada faktor akses ke pelayanan kesehatan (baik itu akses tempuh danjarak ke fasilitas kesehatan). Keterjangkauan akses yang dimaksud dalam penelitian ini dilihat dari segi jarak, waktu tempuh dan kemudahan transportasi untuk mencapai pelayanan kesehatan. Semakin jauh jarak rumah pasien dari tempat pelayanan kesehatan dan sulitnya transportasi maka akan berhubungan dengan kepatuhan berobat.

Hasil penelitian ini sesuai dengan penelitian yang dilakukan oleh Abere Dessie Ambaw (2012) yang menunjukan bahwa jarak serta akses menuju ke rumah sakit memiliki pengaruh terhadap kepatuhan pasien gangguan jiwa. Dalam penelitiannya diketahui bahwa jarak adalah penghalang besar bagi kepatuhan terhadap pengobatan gangguan jiwa.

\section{Pengaruh Dukungan Tenaga Kesehatan Terhadap Kepatuhan Pasien Melakukan Pengobatan Rutin}

Hasil analisis bivariat dari variabel pengaruh dukungan tenaga kesehatan terhadap kepatuhan pasien gangguan jiwa melakukan pengobatan rutin Ke Puskesmas Sidodadi Kecamatan Kota Kisaran Barat Kabupaten Asahan Tahun 2018, dapat lebih rinci pada tabel 5 di bawah ini: 


\begin{tabular}{l|r|r}
\hline Jurnal Penelitian Kesmasy & Vol. 2 No. 1 & Edition: May - October 2019 \\
\hline \multirow{2}{*}{ Received: 24 October 2019 } & http://ejournal.delihusada.ac.id/index.php/JPKSY & Accepted: 31 October 2019 \\
\cline { 2 - 3 } & Revised: 28 October 2019 & \\
\hline
\end{tabular}

Tabel 5 Pengaruh Dukungan Tenaga Kesehatan

Terhadap Kepatuhan Pasien Melakukan Pengobatan Rutin

\begin{tabular}{lccccc}
\hline $\begin{array}{c}\text { Dukungan } \\
\text { Tenaga } \\
\text { Medis }\end{array}$ & \multicolumn{2}{c}{$\begin{array}{c}\text { Kepatuhan } \\
\text { Pasien }\end{array}$} & Total & $\begin{array}{c}\text { P- } \\
\text { Value }\end{array}$ & $\begin{array}{c}\text { RP 95\% } \\
\text { CI }\end{array}$ \\
\cline { 2 - 3 } & Ya & Tidak & & & \\
\hline Ya & 22 & 3 & 25 & 0.008 & $\begin{array}{c}5.72 \\
\text { Tidak }\end{array}$ \\
\hline
\end{tabular}

Berdasarkan tabel di atas dapat dilihat bahwa pasien gangguan jiwa yang tidak mendapat dukungan tenaga kesehatan tetapi patuh melakukan pengobatan rutin sebanyak 6 orang atau sekitar $15.38 \%$. Hasil uji statistik chi square diperoleh nilai $\mathrm{p}=0,008$ maka dapat disimpulkan bahwa ada pengaruh dukungan tenaga kesehatan terhadap kepatuhan pasien gangguan jiwa melakukan pengobatan rutin Ke Puskesmas Sidodadi Kecamatan Kota Kisaran Barat Kabupaten Asahan Tahun 2018. Nilai RP 5,72 pada $95 \%$ CI $(2,70-12,11)$, yang berarti pasien gangguan jiwa yang mendapat dukungan tenaga kesehatan 5,7 kali cendrung untuk patuh melakukan pengobatan rutin, dibanding dengan pasien gangguan jiwa yang tidak mendapat dukungan tenaga kesehatan.

Menurut teori Lawrence Green (1980) faktor yang berhubungan denganperilaku kepatuhan berobat diantaranya ada faktor yang memperkuat ataumendorong (reinforcing factor) yaitu berupa sikap atau perilaku petugas medis/kesehatan yang mendukung penderita untuk patuh berobat (Notoatmodjo, 2010). Teori ini sesuai dengan hasil penelitian yang menunjukan bahwa adahubungan antara peran petugas kesehatan dengan kepatuhan dalam menjalani pengobatan gangguan jiwa.

Hasil penelitian ini didukung oleh Violita (2015) yang menyatakan adahubungan antara dukungan petugas kesehatan dengan kepatuhan minum obat anti gangguan jiwa $(p=0,025)$. Hal ini karena baik dalam penelitian ini maupun penelitian yang dilakukan oleh Violita menunjukan responden dengan peran pertugas kesehatan yang baik ditemukan lebih tinggi dibandingkan dengan peran petugas kesehatan yang kurang. Dukungan dari petugas kesehatan yang baikinilah yang menjadi acuan atau referensi untuk mempengaruhi perilaku kepatuhan responden.

\section{KESIMPULAN}

Berdasarkan hasil penelitian yang berjudul faktor-faktor yang mempengaruhi kepatuhan pasien gangguan jiwa melakukan pengobatan rutin Ke Puskesmas Sidodadi Kecamatan Kota Kisaran Barat Kabupaten Asahan Tahun 2018 didapatkan kesimpulan yaitu:

1. Ada pengaruh antara sikap keluarga terhadap kepatuhan pasien gangguan jiwa melakukan pengobatan rutin dengan nilai $\mathrm{p}=0,032$.

2. Ada pengaruh antara dukungan keluarga terhadap kepatuhan pasien gangguan jiwa melakukan pengobatan rutin dengan nilai $p=0,002$.

3. Ada pengaruh antara jarak puskesmas terhadap kepatuhan pasien gangguan jiwa melakukan pengobatan rutin dengan nilai $\mathrm{p}=0,004$.

4. Ada pengaruh antara dukungan tenaga kesehatan terhadap kepatuhan pasien gangguan jiwa melakukan pengobatan rutin dengan nilai $p=0,008$.

5. Variabel paling dominan yang berpengaruh terhadap kepatuhan pasien gangguan jiwa melakukan pengobatan rutin adalah dukungan tenaga kesehatan yaitu sebesar 5,871 kali.

\section{DAFTAR PUSTAKA}

Ahyar., 2010. Konsep Diri dan Mekanisme Koping dalam Aplikasi Proses Keperawatan. Diakses:

http://ahyarwahyudi.wordpress.com/2010 102/11/konsep-diri-dan-mekanismekoping-dalam-proses-keperawatan/.

Akbar, Muhammad., 2010. Psikosa (Sakit Jiwa). diakses 26 Januari 2018; http://ababar.blogspot.com/2008/12/skizo frenia.html

Arikunto, Suharsimi., 2012. Prosedur Penelitian: Suatu Pendekatan Praktek. Jakarta: Rineka Cipta. 


\begin{tabular}{l|r|r}
\hline \multirow{2}{*}{ Jurnal Penelitian Kesmasy } & Vol. 2 No. 1 & Edition: May - October 2019 \\
\hline \multirow{2}{*}{ Received: 24 October 2019 } & http://ejournal.delihusada.ac.id/index.php/JPKSY & \multirow{2}{*}{ Accepted: 31 October 2019 } \\
\cline { 2 - 3 } & Revised: 28 October 2019 & \\
\hline
\end{tabular}

Copel, Linda Carman., 2011. Kesehatan Jiwa dan Psikiatri Pedoman Klinis Perawat. Jakarta: EGC.

Dempsey, Patricia Ann., \& Dempsey. Arthur D., 2012. Riset Keperawatan: Buku Ajar dan Latihan. Ed. 4. Jakarta: EGC.

Friedman, Marilyn M., 2010. Keperawatan Keluarga: Teori dan Praktik. Jakarta: EGC.

Garcia, Liana., 2014. Gangguan Jiwa Makin Merebak. diakses 15 Januari 2018; http://www.inilah.com/berita/gayahidup/2009/10/10/165897/gangguanjiwa-makin-merebak/.

Hawari, Dadang., 2011. Pendekatan Holistik Pada Gangguan Jiwa Skizofrenia. Jakarta: Balai Penerbit Fakultas kedokteran Universitas Indonesia.

Irma., 2011. Gangguan Jiwa dan Faktor-Faktor yang Mempengaruhinya. di akses: http://www.minangforum.com/ThreadGangguan-Jiwa-dan-Faktor-Faktor-yangMempengaruhinya.

Keliat., Budi Anna., 2009. Peran Serta Keluarga dalam Perawatan Klien Gangguan Jiwa. Jakarta: EGC.

Keliat., Budi Anna., 2008. Penatalaksanaan Stress. Jakarta: EGC.

Kemenkes RI, 2014. Profil Data Kesehatan Indonesia, Diakses: http://Depkes.co.id. tanggal 29 Januari 2018.

Maramis. W.E., 2012. Catatan Ilmu Kedokteran Jiwa. Surabaya: Airlangga University Press. 